\title{
LIFE NARRATIVES OF SETTLERS IN THE ARINOS VALLEY PROJECT
}

\author{
SILVA, Gildete Evangelista ${ }^{\text {* }}$
}

(a) Phd in Environment and Regional Development. Professor State University of Mato Grosso (UNNEMAT), Juara (MT), Brasil. ORCID ID: http://orcid.org/0000-0003-1679-619x. CURRICULUM LATTES: http://lattes.cnpq.br/6436458894173516

\section{(*) CORRESPONDING AUTHOR}

Address: UNEMAT - Rodovia Juara-Brasnorte - Km 02. CEP: 78.550-000, Juara (MT), Brasil. Tel: (+55 66) 35562940

E-mail: domgill60@gmail.com

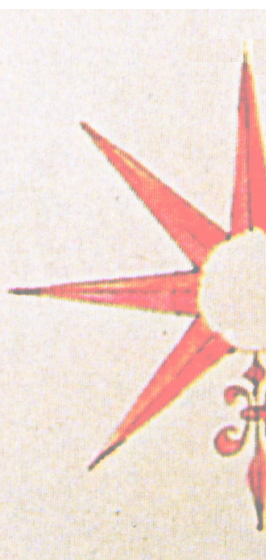

\begin{abstract}
This text deals with the colonization, agrarian reform and rural settlement projects in Mato Grosso. Thus, the main objective was to use the life stories and narratives of the participants in the research on the Arinos Valley Settlement Project to understand their feelings upon arriving at the settlement, their individual and collective life experiences, the dreams, struggles and challenges they underwent in their pursuit of possession of their lot of land in the context of rural settlement. The study is based on the assumptions of the qualitative research method associated with the life stories and narratives of twelve settlers; the selection criterion was that they were the original inhabitants of the settlement. The research data indicate that the narratives expressed in the settler's voices show, on the one hand, their satisfaction and joy regarding the opportunity to fulfill their dream of achieving their own lots of land to guarantee family production. On the other hand, that there are also problems inherent in the neglect and / or lack of commitment of the public authorities, which have not provided the settlers with the basic infrastructure recommended in agrarian reform policies for rural settlements.
\end{abstract}

Keywords: Rural settlements, Colonization, Life stories, Narratives.

\section{RESUMO / RESUMEN}

\section{NARRATIVAS DE VIDA DOS ASSENTADOS NO PROJETO VALE DO ARINOS}

Este texto versa sobre a colonização, reforma agrária e os projetos de assentamentos rurais de Mato Grosso. Assim, objetiva compreender, a partir das histórias de vidas e narrativas dos participantes da pesquisa do Projeto de Assentamento Vale do Arinos, seus sentimentos ao chegarem no assentamento, suas experiências de vida individuais e coletivas, seus sonhos, lutas e desafios empreendidos em busca da posse de seus lotes de terra, no contexto do assentamento rural. O estudo baseia-se no método de pesquisa qualitativa associado ao método de histórias de vida e narrativas de doze assentados, especificamente os primeiros moradores do assentamento. Os dados da pesquisa apontam que as narrativas manifestadas mostram, por um lado, a satisfação e a alegria pela oportunidade que tiveram ao realizar o sonho de conquistar seus próprios lotes de terras para a garantia da produção familiar e, de outro, que existem, ainda, problemas inerentes ao descaso e/ou pouco comprometimento do poder público, ao não disponibilizou aos assentados a infraestrutura básica preconizada nas políticas de reforma agrária para assentamentos rurais.

Palavras-chave: Assentamentos Rurais., Colonização, Histórias de vida, Narrativas..

\section{NARRATIVAS DE VIDA DE LOS ASENTADOS EN EL PROYECTO VALE DEL ARINOS}

Este texto versa sobre la colonización, reforma agraria y los proyectos de asentamientos rurales de Mato Grosso. El objetivo consistió en comprender, a partir de las historias de vidas y narrativas de los participantes de la pesquisa del Proyecto de Asentamiento Vale del Arinos, sus sentimientos al llegar al asentamiento, sus experiencias de vida individules y colectivas, sus sueños, luchas y desafíos emprendidos en la búsqueda de la posesión de sus lotes de tierra, en el contexto del asentamiento rural. El estudio se basa en la pesquisa cualitativa asociado al método de historias de vida y narrativas de doce asentados, los primeros moradores del asentamiento. Las narrativas manifestadas el las voces de los asentados muestran, por un lado, la satisfacción y la alegría por la oportunidad que tuvieron al realizar el sueño de conquistar sus propios lotes de tierras para la garantía de la producción familiar y, de outro, que existen, aún, problemas inehentes al descuido y/o poco comprometimiento del poder público, que no ha puesto a los asentados la infraestructura básica preconizada en las políticas de reforma agraria para asentamientos rurales.

Palabras clave: Assentamientos Rurales., Colonización, Historias de Vida, Narrativas. 


\section{INTRODUCTION}

According to INCRA (2015), Rural Settlement Projects are located in all regions of the country and are made up of independent agricultural units, where families are placed with the intention of using the land to produce goods that will provide them with income and sustenance. According to data from the Institute there are 9,337 rural settlements in Brazil, of which 549 are located in the state of Mato Grosso, with 82,876 families settled in a geographic space of 6,048,948.91 ha.

The Arinos Valley Settlement Project, located in the municipality of Juara, in the northwest region of the state of Mato Grosso, was created in 2003 with the capacity to settle 243 agricultural family units in a total area of $22,800.3725$ hectares. The story of the settlement began with an agreement between the owner of the land and the Rural Workers Union of Juara, to force the Government to declare the land an area of social interest and, at the same time, expropriate it.

The procedures to establish the settlement, the selection process and the planning and implementation of the selection triggered insecurities and doubts in the settlers, who tell their stories of the occupation of the land with a mixture of hope that the lands would be regularized rapidly and fear that they would have to abandon their lots and return them to the landowners. The latter would oblige them to leave behind the improvements resulting from the strenuous work they had performed, as well as their dreams for better living conditions.

This is the context in which the stories of the settlement and the settlers were produced. This study was centered on the search for answers to the following questions: how do the life stories emerge in the narratives of the memories of the settlers of the Arinos Valley Settlement Project? Also, to unveil the complementary questions resulting from the previous question: what were your feelings regarding the process of arrival on your lots of land and the challenges you encountered? In addition, how do you perceive the settlement nowadays?

The text is organized in three sections. The first discusses the method, the data production techniques, the contextualization of the universe of the participants in the research, as well as its operationalization. The theoretical contribution dealing with the rural settlements, the process of colonization and agrarian reform, and the rural settlement projects of Mato Grosso can be found in the second section. The third section shares the settlers' narratives of their life stories, expectations, motivations, dreams, struggles and challenges faced to possess a lot of land. Finally, the considerations reaffirm the need for a greater commitment from public institutions to land reform policies in the country.

\section{MATERIAL AND METHODS}

The study was referenced in the qualitative research method. According to Bogdan and Biklen (1994), this approach enables the production/collection of descriptive data from the direct contact of the researcher with the universe, the social phenomena and the context of the subjects of the reality being studied. This method's main concern is to gain a broad understanding of the different situations and realities interconnected with the research object in question. According to these authors, the researcher's task is to examine the data in its widest relationships, as for qualitative research the data that portrays the phenomena under investigation cannot be conceived of as trivial but instead as generators of multiple meanings.

With this understanding, qualitative research must therefore consider individuals in the environment in which they live, thus it takes into account that context is an integral and determinant part of lifestyles. This assertion is reaffirmed by Lüdke and André (1986) who argue that any kind of research that removes individuals from their natural environment denies the influence of these contextual forces and, consequently, fails to understand the phenomenon studied in its entirety. 
Goldenberg (2003: 49) corroborates these arguments by asserting that "qualitative research data aim at a deep understanding of certain social phenomena supported by the presupposition of social action". For the author, the qualitative approach seeks to understand social phenomena based on subjective assumptions of social action.

There are many methods of data generation in the qualitative approach, among which the life story occupies a prominent place. Referring to this approach, Paulilo (1999) argues that through the oral life story one can understand what happens at the intersection of the individual with the social, therefore enabling elements of the present to be based on past evocations, which gives dynamism to the construction of the social structure.

Through the nature of the phenomenon investigated, that is, the life stories and narratives of the settlers of the Arinos Valley Settlement Project, the intention was to understand the motivations, experiences, and dreams mobilized in the life stories of the settlers participating in this research. In addition, we sought to understand to what extent the life stories acted out in the context of the rural settlement demonstrate individual and collective experiences, as well as the (un)certain marches and struggles in search of the right to land.

The life stories and narratives are part of the characteristics of the qualitative approach to scientific research, since it involves the subjectivity of the subjects studied, that is, with values, feelings, emotions, perceptions and perspectives, among other non-measurable aspects.

Working with life stories and narratives makes it possible to generate qualitative data. According to Porteli (1997), the resources found in this type of survey refer to the subjectivity of those who provide data through oral sources and it has precious elements not found in other sources.

In narrative research, the participants tell the stories of their lives, which are full of setbacks, hopelessness, dreams and struggles, as is the case of the settlers of the Arinos Valley Project who participated in this research. In their simplicity, they narrate the hopes and mobilizations that impelled them to fight for a piece of land. It is these motivations that mobilize them to seek improvements to their living conditions and dignity. This quest for transformation takes place when the subjects gain awareness of themselves in this process of cultural construction.

Goodson et al (2010) point to the importance that the stories we tell exert on multiple social living spaces. For these authors, the stories we tell often portray the facts that we experience in our daily life, whether these are permeated by the feelings that move us, be they the experiences or even the perspectives of individual or collective action. In more detail, the authors assert the potentiality of narratives in life story research:

We tell stories in different contexts and environments, for different reasons and purposes and with different results and effects. Many of our stories are intimately intertwined with our everyday lives. They consist of brief exchanges, short anecdotes, things we want to share with others, either for a specific purpose or just for the sake of sharing. Some stories are factual and descriptive, others express our experience and feelings. And while most stories are about something - an event, an experience, an encounter, a person - they also always express something about ourselves, even if it is just our particular perspective on the situation. Stories serve the purpose of communication; either communicating with others or communicating with ourselves, as in the case of journals or in our 'internal conversations': our reflections, thoughts and daydreams. Sometimes our stories become more reflective and evaluative. [GOODSON] et al, 2010, p. 1-2).

These authors' arguments subsidize the understanding of the narratives of memories of the past told in the present time by the settlers about the process of struggles, appropriation and possession of a lot of land in the Settlement - the universe of this research. According to Goodson et al (2010), these stories may portray the setbacks, the disappointments, the arduous confrontations and struggles of the settlers in search of land, a dream of many people who strive for better living conditions and survival in such contradictory times and uncertain paths for those who dream of a better world, with less injustice and social inequality. 
Regarding narratives and stories, Goodson e Gill (2011, p. 4) highlight three common characteristics, described as follows:

1. temporality - all the narratives cover a sequence of events;

2. meaning - personal meaning and meaning are externalized through the narration of lived experiences;

3. social encounter - all narratives are aimed at an audience and are inevitably shaped by the relationship between the narrator and the listener [free translation]

From this perspective, Goodson and Gill argue that life and narrative are strongly embodied by a mutually constituted relationship, "life is the foundation of narrative, and narrative provides structure, order and meaning to life, and helps to develop meanings in richer and more integrated ways".

Narratives are inseparable from life history, thus they are potential sources to understand the sense that the settlers - the participants in this research - attribute to their life stories that are genuinely mobilized by dreams, hopes, feelings, by the deliberate decision to fight, to tread the (not)paths to make the policies of agrarian reform happen and, above all, moved by the pursuit of justice and social equality. In the course of narrating their life stories, the respondents are mobilized to trigger their memories of the time that portrays the struggles and mobilizations from the initial process of the creation and institutionalization of the Arinos Valley Settlement Project. The multiple setbacks, (un)certain steps and advances, will certainly appear in the stories and narratives of the settlers' memories.

\section{CONTEXTUALIZATION OF THE UNIVERSE, THE PRODUCTION OF THE DATA AND THE PROFILE OF THE INTERVIEWEES}

The field research took place at the Arinos Valley Rural Settlement Project, about 140 kilometers from the headquarters of the municipality of Juara-MT and 890 kilometers from Cuiabá, the state capital. Access to the settled families' land lots is on unpaved and almost impassable roads during the "winter of the region", a period of rains that runs from October to April each year.

The Settlement was established in 2003, through ordinance number 49 of the National Institute of Colonization and Reform (INCRA), published in the Official Gazette of the Union of September 19,2003 . It has the capacity to settle 243 agricultural family units in a total area of 22,800.3725 ha (twenty-two thousand, eight hundred hectares, thirty-seven and twenty-five centares). The lots are organized in five rows according to their geographical positions and the settlers are grouped in four representative associations of producers, where they discuss, make decisions of community interest and plan improvements to the living conditions of the community.

The qualitative research data ${ }^{1}$ was produced through the semi-structured interview, since it favors research that seeks to understand the subjectivity of the subjects interviewed, as well as the individual experiences and particularities of the settlers' world view.

The semi-structured interview was submitted to and approved by the Research Ethics Board of Ahanhguera-Underp University, according to substantiated opinion number 2.231.294 and had the objective of collecting data on the process of creation of the Settlement (planning, structuring of the settlement, selection of the settlers ) and the narratives of settlers' life stories (arrival in the settlement, experiences including dreams, motivations and challenges).

(1) The data were collected in October 2016 and completed in May 2017, due to the torrential rains, above the rainfall average in the region, between November and April, which destroyed bridges, flooded roads and created quagmires, leaving the roads impassable. 
According to Gil (2008), the interview is used in social research for a series of reasons, among which is the consideration that it makes it possible to obtain data referring to the most diverse aspects of social life. Thus it is a very significant technique for an in-depth understanding of data about human behavior.

To produce the data on the life story of the interviewees, the President of the Toca da Onça Association was asked to indicate people to participate in the research, since the selection criterion for the interviews was that they had resided in that universe since its inception.

With this criterion, an interview was carried out with twelve (12) settlers. Of these, five are women, one of whom arrived in the settlement as a child, and seven men. By signing the informed consent form the interviewees agreed to audio recordings of the interviews.

In accordance with research ethics, female settlers will be referred to as MA1, MA2, MA3, MA4 and MA5 and the men denominated as HA1, HA2, HA3 and so forth, as shown in Chart 1.

Chart 1 - Profile of settlers: research participants

\begin{tabular}{|c|c|}
\hline MA2 & $\begin{array}{l}\text { The interviewee is } 49 \text { years old, is Catholic, completed high school, was an elementary teacher in the settlement and has } \\
3 \text { children. The family raises cattle and renders services to third parties to pay the rent, when necessary. She lives in a } \\
\text { wooden house. The family uses motorcycles to get around. }\end{array}$ \\
\hline MA3 & $\begin{array}{l}\text { MA3 is } 65 \text { years old, studied until the fourth year of elementary school, has } 7 \text { natural children and an adopted child, } \\
\text { thirteen grandchildren and four great grandchildren. She is Catholic and the family's main livelihood is raising cattle } \\
\text { that is complemented by her pension as a dinner lady. She lives in a brick house with her husband and a son. They own } \\
\text { a motorcycle for the family's transport. }\end{array}$ \\
\hline MA4 & $\begin{array}{l}\text { Interviewee MA4 is } 38 \text { years old, Catholic, she studied up to the fourth year of elementary school in regular school, and } \\
\text { to complete basic education she took mass examinations. She has two daughters, one } 21 \text { year-old and another aged } 8 . \\
\text { She lives in a wooden house. The family's main income is raising beef cattle and she also provides services to third par- } \\
\text { ties. The family owns a pickup truck that is used for family transportation and cargo. }\end{array}$ \\
\hline MA5 & $\begin{array}{c}\text { The interviewee is } 51 \text { years old, Catholic, has two children and is married to interviewee HA2. She owned a wood shop } \\
\text { before becoming a settler. She lives in a brick house and raises beef cattle. }\end{array}$ \\
\hline HA1 & $\begin{array}{l}\text { The interviewee is } 53 \text { years old. He is a practicing Catholic and studied until the fourth year of elementary school. He } \\
\text { has a couple of children who do not live in the settlement anymore and two grandchildren. His house is a mix of wood } \\
\text { and masonry. He raises beef cattle for his main sustenance. He has a small production of cheese as a complementary } \\
\text { income and also does some small business services. He has a motorcycle that is used as a means of transportation. }\end{array}$ \\
\hline HA2 & $\begin{array}{l}\text { HA2 studied until the fourth year of elementary school. He is married to the settler MA5, they have } 2 \text { children no lon- } \\
\text { ger living in the settlement. He lives in a brick house, his income is from raising beef cattle and he performs purchase } \\
\text { and sale transactions as a complement. }\end{array}$ \\
\hline HA3 & $\begin{array}{l}\text { The interviewee HA3 is } 78 \text { years old, he has } 7 \text { children, } 6 \text { of them married and } 12 \text { grandchildren. He cannot read, but } \\
\text { he can sign his name. He is Catholic. The family's income is based on raising beef cattle and small-scale subsistence } \\
\text { farming, which is further complemented by his and his wife' pension. His house is brick and he uses motorcycle for his } \\
\text { transportation. }\end{array}$ \\
\hline HA4 & $\begin{array}{l}\text { HA4 is } 75 \text { years old, he has } 3 \text { children and } 2 \text { grandchildren. He studied until the second year of elementary school. He } \\
\text { is a Presbyterian. The family income is based on raising cattle, complemented by his pension. He lives in a brick house } \\
\text { and has no means of transport. }\end{array}$ \\
\hline HA5 & $\begin{array}{l}\text { The interviewee HA5 lives in a wooden house, is } 52 \text { years old and single. He attends the Catholic church, raises cattle } \\
\text { for his family income and provides services to third parties as a day laborer. He studied until the seventh year of el- } \\
\text { ementary school and uses a motorcycle as transportation. }\end{array}$ \\
\hline HA6 & $\begin{array}{l}\text { The settler is } 46 \text { years old and completed high school, he is an Evangelical of the Presbyterian Church and lives in a } \\
\text { brick house. His family income is based on milk production and beef cattle. He is married and has three children who do } \\
\text { not live in the settlement. He has a car that he uses for family transportation. }\end{array}$ \\
\hline HA7 & $\begin{array}{l}\text { This interviewee is } 33 \text { years old, married, has a son and completed high school. He is Catholic, lives in a wooden house } \\
\text { and raises beef cattle for his source of income. }\end{array}$ \\
\hline
\end{tabular}

Source: Chart drawn by the researcher (2017).

For the systematization, processing and analysis of the data the methodological-theoretical coding categories proposed by Bogdan and Biklen (1994) were taken as a reference. For these authors, "the development of a coding system involves several steps: it shifts through its data in the search for regularities and patterns, as well as the topics present" (1994, 221). According to Bogdan and Biklen (1994, p. 221), "categories are a means of classifying the descriptive data collected ... so that the material contained in a particular topic can be separated from the other data". From this 
perspective, the life story and the narratives of the interviewees pointed to the analytical categories evident in the research objectives, which consisted principally of understanding the itinerancy, mobilizations and struggles of the settlers in search of a lot of land.

\section{RURAL SETTLEMENTS: COLONIZATION AND AGRARIAN REFORM}

This section presents the theoretical approach that was the foundation of this research and is based on the revision of texts in books, articles, periodicals, among other publications by several authors who have researched rural settlements. This theoretical contribution added to a greater familiarity with the subject researched and is an important subsidy to the reflections, analysis and interpretation of the data produced.

Brazil is a country marked by economic, political, social and cultural inequalities with different characteristics that oscillate between a small part of the population that concentrates a large part of the income, with access to consumer goods, health, security, education and the excluded others, who have a poor quality of life due to the sparse and humiliating financial situations to which they are subjected. This asymmetry or economic and social inequality is present between the regions, states and municipalities of the country and prevents people from having the conditions they need to live with dignity and quality of life.

At present, we see great inequalities between economic and social development models, with significant differences between the south and southeast regions and the other regions of the country. "Economic, social and regional inequalities in Brazil are a problem that affect development as a whole" (GALEANO and MATA, 2009, p. 6).

The main characteristics of economic inequalities are the concentration and irregular distribution of income. In turn, these promote other inequalities such as discrimination and prejudice against several economically less favored social classes. In Brazil, inequalities appear as if they were images of a perverse kaleidoscope, with harmful effects on the low-income population such as precarious education, unemployment, hunger, rural and urban conflicts, extreme poverty, and race and gender inequalities.

An important step towards individual rights and the correction of social injustices came from the promulgation of the Federal Constitution of October 5, 1988, also called the Citizen's Constitution, which presents important advances towards guaranteeing access to citizenship and attending to a wide range of demands from social movements. However, many actions described in the Magna Carta have not been put into action, for example, land ownership problems and public policies aimed at the distribution of properties.

The claims of the countryside are historical and to date have not been fully met, especially the most dynamic actions aimed at the care of those who need land to produce and ensure their and their families' livelihood. Public policies directed to the land issue and access to land in Brazil go back to the colonial period, pass through the first republic and reach the present day.

In this context, it is necessary to differentiate between the agrarian issue that refers to access to property, land exploration and the social relations between landowners and the land reform issues that are related to the dispersion, size and concentration of rural properties in the territory in the hands of a single a family, company, or business conglomerate, called latifundia that generate great local and regional disparities and economic and social inequalities.

The most damaging consequence of land concentration is the great centralization or lack of distribution of income that has economically segregated the majority of Brazilians, the result of contradictory public policies that are notable as the expression of the supremacy of the ruling classes. 
The issue of Brazilian land ownership is characterized by granting advantages to the most economically and financially affluent, to the detriment of the civil and social rights of a large majority of the excluded, who have negligible possibilities of benefiting from the use and possession of land.

The concentration of land ownership in Brazil has its origins at the time of discovery. Government interventions, the fruit of the implementation of various land and agrarian policies, has not been effective in significantly changing the structure of land ownership (RANIERI, 2003, p. 5).

Land and agrarian issues are very complex. They have been and are researched in Brazil by several authors who seek to demonstrate the unjust land distribution to which the Brazilian people have been subjected since its discovery, with a pronounced economic, political and social asymmetry between those who own large tracts of land and those who do not own any. Thus, public policies need to be planned with the social aim of redressing the rights denied to a large part of the population in the distribution of land, actions that require a great deal of social management and justice for the countryside.

From the 1960s, colonizing development policies were created with the intention of solving social conflicts in the Centre-South of the country and populating the Amazon. However, many of these political plans only increased the hegemony of the agrarian elites by granting them credit and incentives that were major strategies for the expansion of capital.

Starting in the 1970s, the policies established for the occupation encouraged unprecedented migrations to the State of Mato Grosso by transforming savannahs and forests into land producing commodities for agribusiness. Rapid economic, political, and social transformations served as an anchor to justify colonization by undertakings that devastated the environment through felling, burning and the overuse of agricultural pesticides and fertilizers, flung into the soil to ensure planting productivity.

The transformations were very fast for the region. "The occupation of the state lands until the middle of the last century was a slow process characterized by several stages starting with the capture of Indians to serve as "slave labor in the main mercantile centers of the Colony" (SILVA and SATO, 2010 , 262). Subsequent stages involved the extraction of precious stones, the exploitation of rubber, cattle raising and, more recently, the timber industry and agribusiness. These economic activities happened, or happen, simultaneously, with one always having supremacy.

Currently, the state's economic expansion is largely a consequence of the expansionist policies instituted by rulers who created measures to establish productive activities in this new agricultural frontier, with the occupation / reoccupation of vast areas of land where thousands of families were settled, mainly coming from the southern states of the country, which, at the present juncture are grain producers for agribusiness, mostly destined for export and, at the same time, strengthening the generation and maintenance of foreign currency by both producers and the country.

In Mato Grosso, in the 1950s, the use of the terminology of colonization in official discourses "took on a specific meaning", inserting itself "[...] in the policy of occupation of empty spaces with immigrant labor to the North of the state, destined to the formation of population nuclei and agricultural production" (SILVA, 2004, pp. 16-17).

However, the settlements implanted in the state are not the agrarian reform announced by the elites and military government responding to the constant struggles of social movements, since this relates to public policies focused on social issues of land distribution to those who do not own any, be they public or private. Colonization deals with settlements created by the public authorities or by private companies in land devolved by the state. That said, Graziano $(1985$, p. 74$)$ asserts that:

Colonization takes place on previously unoccupied land, usually devolved land (without owner) by the State. Land reform, on the other hand, is carried out on land with an owner, that is, on private lands, whether private or government: for this reason agrarian reform basically implies a change of 
land ownership for individuals who are not owners. That is to say: new owners are created among the

"landless" from lands that were already owned by someone else.

Stedile (2011) emphasizes that in the political literature, agrarian reform affects the study and analysis of the issues that the concentration of land ownership brings to the productive forces of a society. Oliveira (2007) corroborates these arguments in saying that agrarian reform consists of government policies designed to modify the land ownership structure through distribution of possession and ownership of land.

Although reform and colonization are related to the countryside, it is necessary to deepen these themes in order to understand what they really are. Colonization aims at the occupation of uninhabited lands by establishing families and making them productive. Agrarian reform is characterized by reforming and modifying existing structures to meet social interests, correcting the juridical relationships of land ownership to serve the interests of society (IOKOI et al., 2005).

Agrarian Reform is a process whereby public policy makers guarantee the distribution or redistribution of rural properties so that they fulfill the social function attributed to them. Sparovek (2003) stresses the importance of carrying out diagnoses and actions to implement agrarian reform settlements, since these are potential tools in the effectiveness and consolidation of the management of public policies and governmental actions.

Agrarian Reform is characterized as a complex policy that should not be understood only as land distribution, but as a complete program that as well as land tenure, benefits rural workers by providing them with housing, education, transportation, health, logistics, credit and also technical assistance with information on planting, production, processing, transport and sales, among others. Agricultural policies for agrarian reform should have as their main characteristic authentic actions for the distribution of land, the possession and use of which would promote equity of rights and social justice. However, there is a historic difficulty in their effectiveness, since land is still concentrated and is the privilege of the few capitalist landowners who use it as merchandise and organize themselves politically and economically to maintain the continuity of this process.

Agrarian reform was not able to adequately fulfill its social role of placing the workers in the countryside. Oliveira (2003) asserts that social, political and economic reasons are fundamental to discuss the issue of the political disputes and how they are traditionally conducted; social projects are implemented according to the interests of those groups that are in power. This fact characterizes a relationship of dependence and social domination.

In view of the historic contradictions perpetuated in the country, where power prevails in the hands of large landowners and the great, hegemonic and conservative political forces that trace the destinies of the nation, the need is emerging for a debate on the democratization of land, from the perspective of the principles of a coherent agrarian reform program.

With respect to the obstacles to the consolidation of public agrarian reform policies, Oliveira (2007) affirms that agrarian reform is an imposition by capital to solve the problems arising from the concentration of land. According to the author, the greatest obstacle to the implementation of agrarian reforms is the fact that rulers have not been able to guarantee the expropriation process from the perspective of the capitalist dictates responsible for creating social conflicts and pressures. Thus, agrarian reform is part of structural actions to balance or reduce the social pressures resulting from the concentration of land in large latifundia. With this, the struggle for land ownership should not be only restricted to access, but also against those who own the property of the latifundia, or rather, the owners of capital.

In the Midwest and the Amazon, capital's advance of over land has been encouraged since the government of Getúlio Vargas, who argued in his speeches for the need to integrate these regions into Brazil, by means of settlement policies, with the justification that it was necessary to occupy what were called demographic voids, in order to integrate them into the national territory so that they could become productive for the market; the March to the West was created for this purpose (BARROZO, 2008). 
The march to the west, announced in 1938 by President Getúlio Vargas, is a symptom of the government's concern to occupy "great voids", in order not only to maintain the country's politics but also, in the words of Getúlio Vargas, to fill the empty spaces between the "economic islands" that formed Brazil (CASTRO et al., 2002, p. 29).

From the 1960s, the military Government initiated several actions to occupy the Centre-West and the Amazon, which favored, above all, large landowners and attracted national and international capital by granting tax incentives, initially, to set up pastures and, soon after, to plant extensive plantations for the development of agribusiness. The military regime opted to hasten the occupation process, defining its form of implementation with the motto that these voids should be integrated into Brazil to avoid them being handed over to supposed foreign powers (MARTINS, 2009).

The lands of the State of Mato Grosso were widely subjected to the occupation policy of the State and Federal Governments through an intense process of propaganda, transforming them into merchandise, with the rationale that they should be occupied, conquered, productive and integrated into the economy of the Centre-South of the country.

The legal history of the land in Mato Grosso shows how the lands passed from the public domain to the private domain, as the laws regulating the land acquisition process, served as political mechanisms to support a land policy aimed at creating the modern territorial property, in accordance with the interests of the classes that dominated and commanded the state's economic and political power, especially the landowners, for a long time (MORENO, 2007, 63).

In this scenario, colonizing companies were politically and economically strengthened in the state and facilities and benefits were made available to them. This, in turn, enabled the preservation of the military regime, in a two-way street.

Thus, colonization in the state, presented as a concern to distribute land to landless families, was actually characterized by the delivery of unoccupied land to private enterprise and to capital, as strategies intentionally organized to prevent the expropriation of latifundia owned by the hegemonic class. Private companies seized large tracts of land and made their enterprises highly profitable with the resale of properties and lots of land in the region to the settlers. According to Schaefer (1985, p. 54), "these so-called social activities were purely capital's actions over the underprivileged population".

\section{THE LIFE STORIES AND NARRATIVES OF THE SETTLERS OF THE ARINOS VALLEY SETTLEMENT PROJECT: THE QUALITATIVE DATA IN ANALYSIS}

This section presents excerpts from the narratives and their respective analyzes. Life stories and narratives are potential sources to understand the expectations, dreams, wanderings and subjectivity, as well as the plans and struggles of the settlers, who participated in the research, in their search for a piece of land, more dignity and better living conditions.

The Arinos Valley Settlement Project was created in 2003 and, like many others, the settlement is the result of claims for a piece of land by those who did not own any. Although rural settlements are not only created by the process of agrarian reform, when this is characterized by a change of land ownership from landowners to landless rural producers, these become an area of inclusion, such as in the Arinos Valley Settlement Project. Despite having been created with little infrastructure, it is evident in the voices of the settlers that arriving on their lots, in addition to conferring the benefits of land ownership, was also the fulfilment of long-held dreams of opportunity and equality 
of rights, as demonstrated by the excerpts of the interviewees narrating how they felt when they took possession of their land:

HA5: When I arrived I did not believe it. I was happy, fulfilled. The land was mine. I owned a piece of land just like a lot of people, even though I did not have the documents for it, like I still don't have today, but the feeling was ownership ... It was all wild, there was everything to do here, but I felt happy. I never tired of looking round me, at my lands! (Narratives produced on 05/18/2017)

MA4: I felt happy to get to place that would be mine, ours. It was hard at the time, but at the same time, when we arrived I felt very happy because we had not been able to acquire anything. Now we owned a small piece of land like a lot of people. That was it, I was happy to arrive in a lot that would be ours. (Narratives produced on 05/18/2017)

HA6: When I got to the lot that they gave me my feeling was of happiness and pleasure at the same time because I was there. Mainly being the owner of a piece of land like many others in the settlement. I couldn't buy a piece of land. I was happy. We did not even know that we would have so much trouble clearing the site, planting and staying on the land. (Narratives produced on 10/20/2016)

Being the owner of their piece of land also emerges in the narratives of MA3 in expressing joy and concern at the same time:

MA3: I felt very happy when I got to the lot. I had never had a piece of land and had no way of buying anything, much less land. But now that land was mine ... Only it was all forest. I had nothing, but I was still coming to what was mine, what was ours. The homestead was made near the river to facilitate access to water. (Narratives produced on 05/18/2017)

The lack of government action, the institutions' lack of commitment in fulfilling agrarian reform policies, the settlers' lack of experience in working in the countryside, the lack of resources for survival have caused many to abandon or sell their lots at any price and return to their origins, or seek other places to live, so that there are few settlers now than at the beginning of the settlement.

The Arinos Valley Settlement Project has some characteristics similar to others, such as the origin of the settlers, and others are different, like the settlers' activities prior to being granted lots of land.

In the Arinos Valley settlement the settlers already resided in nearby towns in the Arinos Valley, near the settlement. This resembles Pirituba Settlement Project, located in the municipality of Itapeva, in the state of São Paulo. The population of this settlement was also made up of settlers from the region: "the population of this settlement originates mostly from the region itself, mainly from the municipalities of Itapeva, Itaberá, Itararé, Coronel Macedo and Itaporanga" (IOKOI et al, 2005, 38).

The activities prior to the settlement are somewhat different in these two settlements. While the settler population of the Pirituba Settlement Project were 99.7\% agricultural workers (IOKOI et al, 2005), in the Arinos Valley Settlement only 65\% of settlers were formerly farmers. The others were from various trades, such as joiners, bricklayers and salespersons, among others.

Another important feature of the Arinos Valley Settlement Project is how it was created. It started with an agreement between the farm's owner and the Rural Workers Union to invade the area, to force the government to declare it as of social interest for land reform and expropriate it to settle landless families.

The union registered the candidates, authorized their entry and organized the lot demarcation services. Incra only continued the initial work by granting the documentation, carrying out the consultations required by the legislation, legitimizing the selected settlers and conducting the other 
stages of the agrarian reform bureaucratic work. The candidates of the settlement viewed these selection procedures with suspicion and also had doubts as to whether the settlement would be regularized by the federal government.

The interviewee HA1 narrates how settlers were guided to land tenure in the settlement and shares his fears in the face of uncertainties about their legalization:

HA1: We applied to the union and the union distributed and indicated the lots. At the time nobody in the settlement had papers. From there the Union was registering everyone and was dividing the lots and distributing them. They started measuring because when we got here the lots hadn't been measured yet. It was a mess ... [...] Each one made his demarcation. Years later we all paid to do the GEO. It was all a risk and everything was uncertain ... Before we came here, we signed a document at the union that they called a deposit for 3 years. If the government did not acquire the area to be transformed into a settlement, we would have to leave the lot, abandon the houses, the improvements and all the work we had done. (Narratives produced at 20/10/2016)

The narratives of the interviewees HA5 and MA4 also express the feeling of insecurity and fears about the procedures of the legalization process of the settlement by the Federal Government.

HA5: We applied for union membership. Even paid a fee ... Then they would send people to the settlement to work on the land. The lots were indicated by the union but we had to sign a document. They said that this was a loan system. It was like this: you went to the settlement and started working while the union and politicians negotiated with the government to expropriate the land. If there was no expropriation of land, we would have to go, leaving behind the work and the improvements. It was a big risk. How to leave behind something built with so much effort and with so little money, if the lands were not expropriated? It was a risk, yes. (Narratives produced on $05 / 18 / 2017$ )

MA4: We learned about the settlement on the street and went to find information at the union. I remember that we paid a seventy reais registration fee, I've kept the receipt until today. We then attended a meeting and were informed that there wouldn't be ownership of lots in the settlement yet. It was a kind of loan for three years. If the Government did not pay compensation to the owners of the land, we would have to leave. So we went to the lot. Actually it was an uncertain step that we took. I see it was a huge risk, because we could be evicted at any moment. (Narratives produced on 05/18/2017)

During processing of the documents to regularize the settlement there was a lot of information that frightened the settlers. The interviewee HA7 narrates his uncertainties about this process:

HA7: We went to the union, we registered and the union sent us to the settlement. The settlement was not yet regularized and when we arrived on the lot it was all bush. Gradually we opened the bush and worked the land. It was an uncertain step for us to take ... There was nothing certain, it was all speculation. The union did not want to give us a copy of the loan term. A lot of people said that we would soon be evicted from the lots, leaving our work and our things for the landowner. Every day was full of a terrible apprehension. We were afraid. (Narratives produced on 05/18/2017)

These excerpts from the narratives demonstrate the non-compliance of the National Institute for Colonization and Agrarian Reform (INCRA) of paragraph "a", of the second paragraph, Article 2 of the Land Statute, Law 4,504 / 64, which determines that it is the duty of the public authorities to promote and create conditions of access of the rural worker to land ownership. There is also noncompliance with Article 55, since it determines that colonization is the responsibility of the public authorities and it shall take the initiative to recruit and select people or families, inside or outside the national territory, gathering them in agricultural centers or agribusinesses, taking care of their transportation, reception, lodging and guidance to their placement and their integration in the respective nuclei. 
The actions taken by the Union of Rural Workers to select the settlers, despite having been fundamental for the existence of the Arinos Valley Settlement Project, generated insecurity and fear among the candidates for a plot of land, since this was an activity that should have been carried out by Incra. In addition, it was not certain that the settlement would be regularized, since rural settlements must be created on land already incorporated to the Public Patrimony after being declared of social interest for agrarian reform.

The narrative of MA3 shows that there were many challenges to be faced and circumvented in the settlement:

MA3: For me one of the challenges in the settlement was the lack of transportation and the precariousness of the roads. The bus stop was far away, we got off and arrived at the settlement one, two o'clock in the morning. We had to leave the shopping and the school pack lunch and find a way to get it later. At first I brought the groceries and everything I needed on my back and then we bought a cart. So we would arrive at the bus stop, leave things, walk home, get the animal from the pasture, hitch it to the cart and go get what we had left behind at dawn. The road was still bad, it was a track. The road is still bad, but its improved a lot because we asked for help from City Hall, who occasionally fix it for us. But we passed through a lot of hardship. First, because we did not have money and also because of the bad roads. In the times of the floods the food ran out and there was no way to go to Juara because the buses couldn't reach the settlement for two months. You know what we ate? As we didn't have chickens or other stock, we brought a lot of chicken broth and made a paste with manioc flour and ate it. (Narratives produced on $05 / 18 / 2017$ )

Interviewee MA3, in his narratives adds that the challenges encountered were also due to the neglect of public bodies that did not provide the necessary infrastructure to the Arinos Valley Settlement Project.

MA3: When we arrived at the settlement it was all bush. We cleared the trees and cleared the area without INCRA support or assistance. Before heading to the settlement, we heard in the union that we would have rights like roads, bridges, houses, credit, technical assistance and rural guidance but we did not receive anything. We were abandoned. Today things are better but my husband always says that we took a daring step and if he had known what we were going to go through he wouldn't have come to the settlement. (Narratives produced on 05/18/2017)

The lack of infrastructure is also narrated by the interviewee HA7 as one of the problems found in the settlement:

HA7: We did not have good roads to reach the settlement. It was difficult for us to access the lots and also to bring what was needed for our continuity on the lots. There were many difficulties that made me wonder if my wife and I did the right thing in coming to the settlement. But for me, I'm a father, the greatest challenge was the precarious schooling. I have a son and the school in the settlement was very bad. Many families ended up going to town in search of better schooling conditions for their children. (Narratives produced 05/18/2017)

Article 16 of the Land Statute shows that Agrarian Reform aims to establish a system of relationships between man, rural property and land use, capable of promoting social justice, progress and the well-being of the worker. However, in the Arinos Valley Settlement Project, INCRA did not fulfill these guidelines, since the families were settled and left to their own devices, without being offered the necessary financial support to establish themselves or the other credits provided for settlers. Also lacking were basic infrastructure such as electric power, water, roads and housing, rural technical assistance and education.

The issues related to the lack of infrastructure are narrated by all the settlers, but there were others as narrated by interviewees HA6 and HA5. 
HA6: The biggest challenge was to turn it all into a place. It was all bush and we could not afford it. It was disheartening not to have the money to deforest, plant, fence. In addition, what we produced the animals ate. There were a lot of pests... Pig, tapirs, capybaras ... Nothing worked. So we chose to plant grass and we started to raise cattle. So for me the biggest challenge was to clear the site because we did not know the region, the land. The soil was sandy, the pasture didn't work, the grasslands were weak, the cattle would die. Gradually we were learning to live in the settlement, so we were avoiding the challenges we encountered. We also learn to fight collectively through our association. Thus, we fought with state and municipal secretaries, with the city and they gradually met some of our demands. (Narratives produced on 05/18/2017)

In HA6's narratives there is evidence of overcoming the condition of individual private owner and learning to work collectively in the search for rights and citizenship.

HA5: The problems were many. We did not have roads; access was very bad. It was just a track that allowed walking. Things like equipment and food were carried on our backs. We did not and still do not have health care. Incra did not assist or demarcate the lots and we had to pay for it. The city council did little to help with the clearing of the settlement, but the biggest challenge we encountered was the lack of knowledge of the region and the environment. When we arrived, the cattle died very fast from an unknown sickness. It took us a while to discover that it was the ingestion of an herb called "vicki" that infested the entire region. We managed to get around many problems with a lot of work, sometimes individually, other times collectively. We were also learning to hear and feel the place. Little by little things got better.... (Narratives produced on 05/18/2017)

To MA1, the biggest challenge found by her family was clearing the site and working on land that they didn't know.

MA1: It was important for me to clear the site, make it habitable, productive. Here it was only bush and we wanted to produce cattle, but we did not have money and we didn't know that the place that was full of animals. We hardly ever saw the jaguars, but we saw their tracks and we heard the noises they made in the woods. I was a kid and I walked to school. So think about how I felt about having to walk a long way, alone and afraid. (Narratives produced on 05/19/2017)

The selected settlers were not all landless farmers and even those who were accustomed to rural life had difficulties coping with a new region, so much so that it took them time to figure out why the cattle died and that without acidity correction the sandy soil was unfit for agricultural production. As they did not have rural technical assistance or any other training planned and executed in the settlement, they were unprotected and unable to cope with the diversity of the countryside, which would enable them to produce their livelihood.

At present, the Settlement, despite having many problems, is considered by the respondents as a good place to live. The interviewees MA3 and MA4 narrate their lives in the settlement as follows:

MA3: I think living in the settlement is good today. It's way better than when we came here. My life is to take care of what is ours, our creation. We have pigs, chickens, cattle. I really like living in the settlement. Here it is tranquil, it is peaceful. We work hard, struggle all day, but when night comes, we sleep in peace ... (Narratives produced on 05/19/2017)

MA4: Compared to how to was before it is very good. We have more quality of life compared to the beginning of the settlement. We even have a truck to load things. It cannot be said that everything is one hundred percent, but today it is possible to live better, to eat better. And, today we work only on what is ours. We don't have to work outside anymore. (Narratives produced on 05/18/2017) 
The excerpts from MA1's narratives reaffirm the stories of MA3 and MA4, as we can see:

MA1: Today it is good to live in the settlement. We have to electric light. When we arrived there was no power and we lived with lamplight. As we also work with milk production, today we can use the cooler. Nowadays, we have a wooden house but it is a good house, the place is clean, we have milk and beef cattle and the roads are better. Today, I really like living in the settlement. There have been important changes and we do not need to beg for everything, today we know how to demand more from the authorities. I live with my parents and we are happy in the settlement. (Narratives produced on $05 / 19 / 2017$ )

The narratives point to significant improvements in their living conditions after the access to and ownership of their lots. When asked about life in the settlement, they have highlighted several improvements in basic infrastructure such as roads, schools, electric power, housing, family income, etc. which are essential for their permanence on their lots of land. With this, it is possible to infer that if the quality of life has improved, it is because there has also been significant economic, social and political development in the settlement. When they reflect that they work with what is theirs, that they take care of what is theirs, that there have been changes and that they know how to demand their rights, there are in these narratives the feeling that somehow they knew how to fight for the right to conquer the land.

The awareness of their citizenship, their rights and duties, makes the workers active participants in social processes, organizing themselves in the defense of their interests ... As a result, they come to interact and press the authorities so that their claims are met, becoming significant political actors in their communities (SPAROVEK, 2003, p. 26).

The research participants report that the settlement is much better than it was years ago, but they lack infrastructure that could enable them to have a better quality of life. The interviewee MA5 narrated what is lacking in the settlement: "we still lack a covered area for our leisure there in the church, we need a telephone to communicate with the city, we need more attention in the area of health and, especially, better schools".

This feeling is manifest in the narratives of HA3 and HA6:

HA3: The Arinos Valley settlement today is very good to live in. But we still lack the political interest to bring us more improvements. In my opinion there is a lack of incentive to increase our production and income and, moreover, roads are lacking. (Narratives produced on 10/20/2016)

HA6: The settlement is good to live in despite everything. If we had more structure it would be better still. I think education is precarious, not the teachers, but how it is offered (Narratives produced on 05/18/2017)

The settlement, in the narratives of the interviewees, is characterized as a good place to live, but everyone believes that the basic infrastructure must be implemented or improved, such as: health, education, roads, leisure, etc. These claims demonstrate that the community has politicized itself and has perceptions of its rights in search of the full exercise of citizenship, based on its conquests. For Sparovek (2003), when the settlers take control of their land, they go through major changes and feel more responsibility for their fate, so that they demand more and require more individually or collectively from institutions.

The settlers were asked about what motivated them to live in the Arinos Valley settlement. The interviewee MA3 emphasizes: 
MA3: Because I like to live on my piece of land. It has provided an income for our survival. I know that in the past we risked a lot coming here, it was all uncertain but for us everything went well. I feel happy here. In addition, in the settlement we have an association and in it we have strength. (Narratives produced on $05 / 18 / 2017$ )

The interviewee MA2 says what motivates her to live in the settlement: is the quiet and the issue of affectivity. At first we were not sure of anything, we only dreamed of a piece of land. Whoever has been here from the beginning has suffered and has, in a way, won. That is what keeps us here until today.

The interviewee HA5 also expresses his motivation in narrating:

What keeps me in the settlement is the tranquility and I think because I feel fulfilled. I always wanted to have a little piece of land. Now I have it. That feeling gives me a bit of security. Is no longer something uncertain, that could happen. This has already happened, it is a certainty. In addition, there is our community work. In the beginning, if Incra had done little of what it should have done, I cared little. Then I was getting into things, the process, the rights of settlers and I began to join in the Association. Today I am a member, I am part of a community. (Narratives produced on 05/18/2017)

On the part of the settlers these narratives involve the feeling of belonging to the community, the group of people who arrived in the settlement, struggled and continue to live there today. For Farias (2003), this feeling is a subjective bond that is related to the feeling of belonging with possibilities of fulfilling desires and recognition.

Some evidenced their dreams as rural settlers: "my biggest dream is the definitive documentation (interviewee HA6). "My dream is that the settlement provides an income to the people who live in it " (interviewee MA1). "I dream of better incomes and easy access to take production to the city " (interviewee HA5). "My greatest dream is to live". Interviewee MA4, is deeply moved and weeps as she says: "Our story is a story of suffering, we faced difficulties. But it's a life story. Not just one, but many lives. Only those who believed and fought understand this story".

The dreams of the settlers researched the Arinos Valley Settlement project are consistent with their trajectories and struggles. It can be seen in the narratives that, somehow, they built spaces that allowed the intersection of social relationships between them in the community, which contributed to their permanence in the settlement. In this way, their dreams are intertwined with life stories and struggles and project the continuity or development of these spaces of social relationships, to develop not only the aspects inherent to the infrastructure, but also those that concern the process of personal and political formation by adopting militant positions within the individual and collective life of the settlement.

The settlers' life stories emerge as prominent acts of courage: residing in a distant place, with precarious roads, no physical infrastructure, and still with little support from government institutions, like an epic of tentative steps that occurred for some as uncertain steps or decisions that they took when they decided to go to the settlement, and for others, as courage and a struggle in search of a fair share of land, a space that would allow them to produce and have an income for their livelihood and their offspring.

\section{FINAL CONSIDERATIONS}

The creation of the Arinos Valley Settlement provided access to land for workers living in the municipalities of the Arinos Valley, in a bureaucratic process that began at the Union of Rural Workers of Juara and was complemented by the National Institute for Colonization and Agrarian Reform (INCRA). The change from being landless workers to landowners has had consequences for the settlers' social and economic relationships and new social actors have emerged in the settlement, who have acted in the economic, social and political scenarios. 
The peculiarities in the selection, how the works to settle the selected workers were conducted, the lack of infrastructure and the difficulties found by the settlers protagonized stories, which cannot and should not be forgotten. In this context, this article shares the life stories and narratives of memories of the settlers of the Arinos Valley Settlement Project.

The data set shared in this research shows that the life stories narrated by the settlers emerge as a courageous decision to live in a settlement far from the urban nucleus, with barely usable roads, with little infrastructure and almost without assistance from governmental institutions.

The narratives of the settlers show that their feelings when arriving in their lots were of joy and happiness, that they looked at their land and they did not tire of admiring it and appreciating the landscape in a state of contemplation. Their arrival had a special significance; their insistence on the struggle for land had not been in vain and they believed that their lives would improve once they took possession of it.

But not everything was easy for the settlers, they narrate that they soon realized the challenges to be overcome such as the lack of transport, bad roads, lack of money and financial credit, lack of basic infrastructures like schools, bridges, health posts, housing and water. In addition, because they were unacquainted with the environment, it took time to realize that family farming was not viable without correcting the soil or that the cattle would die suddenly due to the region's vegetation. They emphasize that they have managed to circumvent several of these problems / challenges with much work, individual or collective, and have learned to listen to and feel the place.

The narratives of the interviewees allude to the fact that access to land, the ownership of the lot and the works carried out are important subsidies, but not sufficient to enable conditions for production, income and quality of life. Thus, it was difficult for the settlers to remain in the settlement without the means necessary for productive activities, such as machinery, equipment, supplies, credit and also the knowledge not only of how to produce but of the natural environment of the region.

The struggle for land ownership made it possible for settlers to perceive the settlement as a space to develop policies and power, as they felt stronger and more confident through collective struggles in their associations. The lack of support from Public Institutions such as Incra and Empaer, coupled with the precarious infrastructure provided for them, has made the settlers become social actors in search of their interests and their rights.

The excerpts from the settlers' narratives point out that in the Arinos Valley Settlement, the constant struggles for land gave the settlers political experience and produced decentralized forms of leaderships, representations and organizations through their associations and also through other forms of organizing themselves in search of their demands. In addition, the creation of the settlement has been configured as the end point of a procedure that dragged on for years; uncertain and doubtful. However, it was a starting point from which the settlers perceived possibilities to insist and fight for feasible options, not only economic, but also infrastructure such as schools, health service, good roads, credit and technical assistance. This is the march for the land that is no longer an uncertainty, but is the result of abundant struggles, sacrifices and victories.

\section{BIBLIOGRAPHIC REFERENCE}

ARAUJO, M. S. S. Desenvolvimento e militarismo na Amazônia. In. GARCIA, D. S. C.; MICELI, P. C. (Org.). História e fronteira. Cáceres-MT: UNEMAT Editora, 2014. 223p.

BARROZO, J. C. Políticas de colonização: as políticas públicas para a amazônia e o centro-oeste. In. BARROZO, J. C. (Org.). Mato Grosso do sonho à utopia da terra. Cuiabá: EdUFMT/Carlini \& Caniato Editorial, 2008. 336p.

BOGDAN, R.; BIKLEN, S. Investigação qualitativa em educação: uma introdução à teoria e aos métodos. Porto Editora: Portugal, 1994. 336p. 
BRASIL, Lei 4.504, de 30 de novembro de 1964. Dispõe sobre o Estatuto da Terra, e dá outras providências. Diário Oficial da República Federativa do Brasil. Brasília, Seção 1 - Suplemento - de 30/11/1964, p. 49.

BRASIL. Ministério da Integração Nacional. Distribuição dos incentivos fiscais aprovados por estado (2007 a 2015). Disponível em Http://www.suadam.gov.br/index.phpqincentivos-fiscais. Acesso em 02.03.2017.

CASTRO, S. P.; BARROZO, J. C.; COVEZI, M.; PRETI, O. A colonização Oficial em Mato Grosso: a nata e a borra da sociedade. 2. ed. Cuiabá: EdUFMT/NERU, 2002, 236p.

DATA LUTA. Núcleo de estudos, Pesquisas e Projetos da Reforma Agrária. Relatório 2012. http:// www2.fct.unesp.br/nera/boletim.php. Acesso em 30.05.2017.

GALEANO, E. A. V.; MATA, H. T. C. Diferenças regionais no crescimento econômico: uma análise pela teoria do crescimento endógeno. Revista Econômica do Nordeste, Fortaleza, v. 40, n. 4, p. 669-684, 2009. GIL, A. C. Métodos e técnicas de pesquisa social. 6. ed. - São Paulo: Atlas, 2008. 131p.

GOODSON, I. F.; BIESTA, G.J. J. G.; TEDDER, M.; ADAIR, N. Narrative learning. London; New York: Routledge, 2010. 137p.

GOODSON, I. F.; BIESTA, G.J. J. G.; TEDDER, M.; ADAIR, NGILL, S. R. Narrative pedagogy: life history and learning. New York: Peter Lang, 2011.174p.

GRAZIANO DA SILVA, J. F. Para entender o plano nacional de reforma agrária. 2. ed. São Paulo: Editora Brasiliense S.A, 1985. 103p.

INCRA - Instituto Nacional de Colonização e Reforma Agrária. Assentamentos. Disponível em: http:// www.incra.gov.br/assentamento. Acesso em: 23 mar. 2016.

IOKOI, Z. M. G., ANDRADE, M. O.; REZENDE, S.; RIBEIRO, S. (Org.)Vozes da terra: histórias de vida dos assentados rurais de São Paulo. São Paulo: Fundação Itesp, 2005. 256p.

LÜDKE, M.; ANDRE, M. E. D. A. Pesquisa em educação. São Paulo: EPU, 1986. 99p.

MARTINS, J. S. Fronteira: a degradação do outro nos confins do humano. São Paulo: Contexto, 2009. 191p.

MILES, M. B; HUBERMAN, A. M. Análise de dados qualitativos: uma expansão livro de fontes. 2. ed. Londres: Sage. 1994. 248p.

MORENO, G. Terra e poder em Mato Grosso: política e mecanismos de burla - 1892-1992. Cuiabá-MT: Entrelinhas: EdUFMT, 2007. 310p.

OLIVEIRA, F. Crítica à razão dualista. O Ornitorrinco. São Paulo: Boitempo Editorial, 2003, 150p.

OLIVEIRA, A. U. Modo de produção capitalista, agricultura e reforma agrária. São Paulo: FFLCH, 2007, 184p.

PAULILO, M. A. S. A pesquisa qualitativa e a história de vida. Serv. Soc. Ver. Londrina, V. 2, p-135-148, Jul./Dez. 1999. Portal do Brasil. Economia e emprego. Disponível em:

http://www.brasil.gov.br/economia-e-emprego/2015/07/agricultura-familiar-produz-70-dos-alimentos-consumidos-por-brasileiro. Acesso em: 10 jun. 2017.

PORTELI, A. O que faz a história oral diferente. In: Cultura e representação. São Paulo: Projeto História, n.14. Fev. 1997. p.25-39.

RANIERI, S. B. L., Retrospecto da reforma agrária no mudo e no Brasil. In. SPAROVEK, Gerd. A qualidade dos assentamentos da reforma agrária brasileira. São Paulo: Páginas e Letras Editora e Gráfica, 2003. 205p.

SILVA, A. C. F. Nas trilhas da memória: uma colônia japonesa no norte de Mato Grosso - Gleba Rio Ferro (1950-1960). Dissertação (Mestrado em História) - Instituto de Ciências Humanas e Sociais, Universidade Federal de Mato Grosso, Cuiabá, 2004.

SILVA, R.; SATO, M. Territórios e identidade: mapeamento dos grupos sociais do estado de mato Grosso - Brasil. Revista Ambiente e Sociedade, Campinas, n. 2, p. 261-281, 2010.

SOUZA, E. A. História de Sinop: sociedade imobiliária noroeste do Paraná. In: BARROZO, J. C. (Org.). Mato Grosso do sonho à utopia da terra. Cuiabá: EdUFMT/Carlini \& Caniato Editorial, 2008. 336p.

SOUZA, E. A. de. O poder na fronteira: hegemonia, conflitos e cultura no norte de Mato Grosso. Cuiabá: EdUFMT, 2013. 251p. 
SILVA, G. E.

SPAROVIK, G. A qualidade dos assentamentos da reforma agrária brasileira. São Paulo: Páginas \& Letras Editora e Gráfica, 2003. 204p.

STEDILE, J. P. A questão agrária no Brasil: o debate tradicional - 1500-1960. 2. ed. São Paulo: Expressão Popular, 201p. 